\title{
Pemanfaatan Vlog Sebagai Media Pembelajaran dalam Meningkatkan Maharah Kalam bagi Mahasiswa IAIN Kudus
}

\author{
Muthmainnah \\ IAIN Kudus, Jawa Tengah, Indonesia \\ mutmutminzaman@gmail.com \\ Azwar Annas \\ IAIN Kudus, Jawa Tengah, Indonesia \\ Azwarannas273@gmail.com
}

\begin{abstract}
Abstrac: Along with the development of an all-digital era, the learning media also adjusts to this situation. Vlogs, one of the social media, are now a growing trend in society. This social media, if packaged nicely, can also be a very interesting learning medium and provide a plus in improving student abilities. This article aims to describe the use of social media Vlogs in learning speaking skills and students' perceptions of using Vlogs in learning speaking skills. The methodology used by the author in the article is descriptive qualitative. This type is tailored to the purpose of writing articles, namely to provide information and descriptions related to objects. The focus of this article study is students of the IAIN Kudus Da'wah Faculty in the odd semester of the 2019-2020 academic year. The findings obtained by the authors of this study; 1) The choice of Vlog as one of the maharah kalam learning media for students because it has many positive values or advantages, namely it is easy and flexible; cheap and economical; and reminds student creativity. 2) the use of Vlogs can improve performance or confidence in speaking Arabic.
\end{abstract}

Key words: Vlog; Arabic learning; speaking skills

$$
\begin{aligned}
& \text { ملخص } \\
& \text { جنبًا إلى جنب مع تطور العصر الرقمي بالكامل ، تتكيف وسائط التعلم أيضًا مع هذا الموقف. }
\end{aligned}
$$

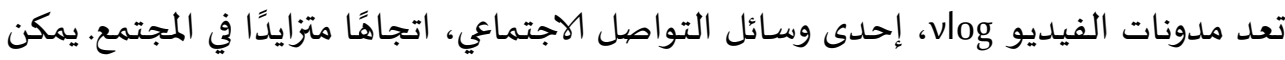




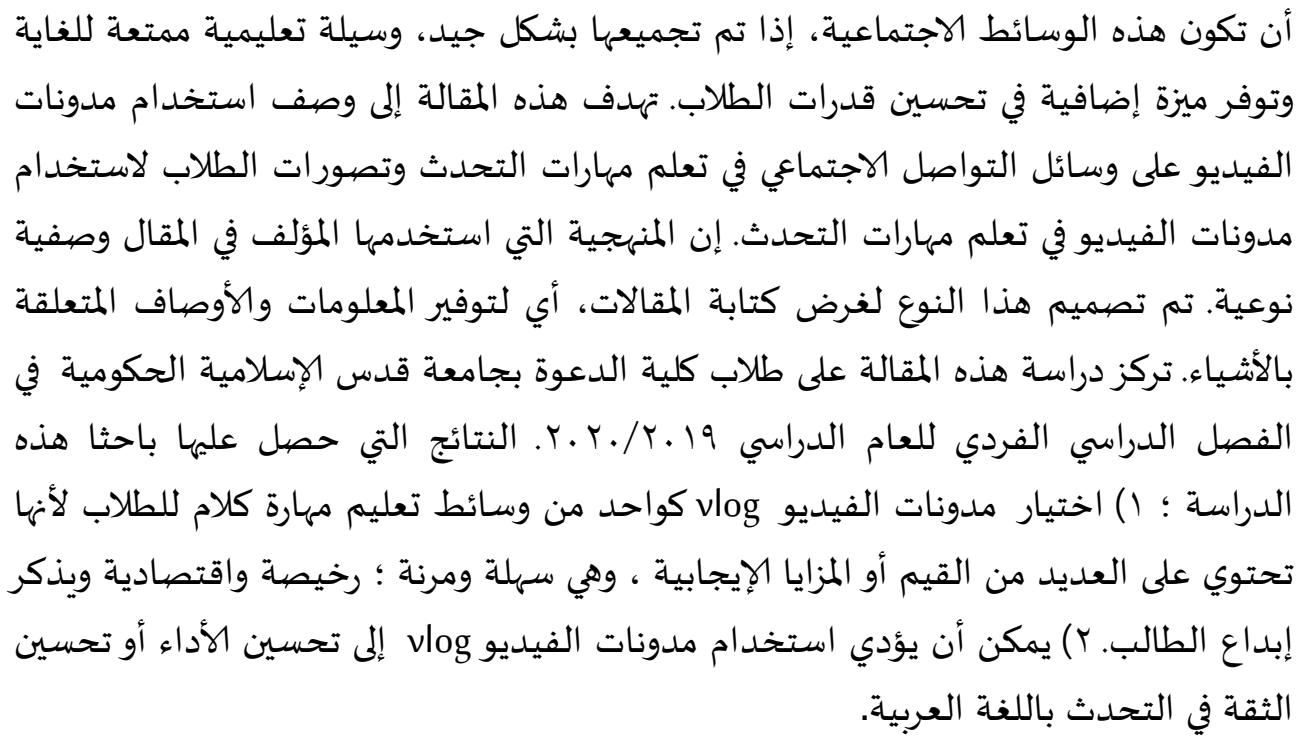

الكلمات الأساسية: مدونة فيديو vlog ؛ تعلم اللغة العربية؛ مهارات الكلام

\begin{abstract}
Abstrak
Seiring perkembangan zaman yang serba digital, maka media pembelajaran pun menyesuaikan keadaan tersebut. Vlog salah satu media sosial sekarang menjadi tren yang berkembang di tengah-tengah masyarakat. Media sosial ini kalau dikemas secara apik juga bisa menjadi suatu media pembelajaran yang sangat menarik dan memberikan nilai plus dalam meningkatkan kemampuan mahasiswa. Artikel ini bertujuan untuk mendiskripsikan penggunaan media sosial Vlog pada pembelajaran maharah kalam dan persepsi mahasiswa dalam penggunaan Vlog pada pembelajaran maharah kalam. Metodologi yang digunakan penulis dalam artikel adalah kualitatif deskriptif. Jenis ini disesuaikan dengan tujuan penulisan artikel, yakni untuk memberikan informasi dan gambaran terkait objek. Lokus kajian artikel ini adalah mahasiswa Fakultas Dakwah IAIN Kudus semester Ganjil TA 2019-2020. Hasil temuan yang didapat oleh penulis dari kajian ini; 1) Pemilihan Vlog sebagai salah satu media pembelajaran maharah kalam bagi mahasiswa karena memiliki banyak nilai positif atau kelebihan, yakni bersifat mudah dan fleksibel; murah dan ekonomis; dan meningatkan kreatifitas mahasiswa. 2) penggunaan Vlog mampu meningkatkan perfomansi atau percaya diri dalam berbicara bahasa Arab.
\end{abstract}

Kata kunci: Vlog; pembelajaran bahasa Arab; maharah kalam

\title{
A. Pendahuluan
}

Pada era digital ini banyak perkembangan begitu pesat dalam segala hal kegiatan manusia. Pengaruh zaman yang serba digital ini membuat semua pakar 
ahli harus beralih pada teknologi. Dari bidang ekonomi, sosial hingga pendidikan. Pada bidang pendidikan semua aktivis pendidikan mau tidak mau harus mengikuti zaman yang serba canggih ini. Tidak menutup kemungkinan para aktifis pendidikan yang masih gagap dalam urusan teknologi harus mengejar tarjet untuk bisa menguasainya. Jika masih berkutat pada zaman yang serba manual pun akan berdampak negatif. Mereka akan termarginalkan dan terhempas pada gelombang globalisasi yang sarat akan kompetisi (Haniah, 2014).

Teknologi telah berkembang dan berdampak pada aktifitas sosial manusia. Dari dampak tersebut lahirlah beberapa aplikasi media sosial . Aplikasi-aplikasi media sosial diantaranya adalah Whatsapp, Telegram, Facebook, Instagram, Twitter, Youtube, dan beberapa media sosial lainnya adalah sebagai bentuk implikasi dari inovasi teknologi yang mengarah kepada aktifitas sosial. Mediamedia tersebut memberikan kemudahan kepada manusia untuk saling berinteraksi sosial dan menjaga kehangatan keluarga atau pertemanan tanpa terhalang oleh jarak dan waktu (Mubarok, 2020). Selain itu juga, hal paling dominan yang kita dapatkan ketika bermedia sosial adalah meningkatkan kepercayaan diri. Seperti penggunaan whatsapp penjelasan dari Halimatus Sa'diyah pada penelitian jurnalnya pembelajaran bahasa Arab bahwa media Whatsapp berperan terhadap pertumbuhan kepecayaan diri mahasiswa untuk berkomunikasi menggunakan bahasa Arab. pertumbuhan kepercayaan diri (selfconfidence) tersebut dibuktikan dengan antusiasme mahasiswa dalam bentuk ungkapan-ungkapan pendapat dan komentar yang sangat variatif pada grup whatsapp. Hal ini bisa kita bandingkan perkuliahan antara via offline dengan online.

Dari beberapa media sosial diatas bisa dimanfaatkan untuk inovasi pembelajaran. Terutama pembelajaran bahasa Arab. Salah satu media sosial yang lagi ngehits di era revolusi industri 4.0 adalah Video Blogging atau yang biasa disingkat menjadi Vlog. Di era digital ini banyak para kalangan yang menggunakan media sosial Vlog untuk meningkatkan kepercayaan diri mereka. Mulai dari kalangan anak-anak, remaja, dewasa hingga usia lanjut. Mereka melakukan aktivitas visualisasi kegiatan inspiratif mereka dengan cara merekam di video kemudian dibagikan ke beberapa media sosial seperti Facebook, Instagram, Youtube dan sebagainya. Meski visualisasi mereka menggunakan media sosial vlog sebagai hiburan semata ada beberapa aktifis pendidikan yang mengikuti trend ini sebagai upaya untuk meningkatkan semangat belajar peserta didik. Mereka pun tidak kalah kreatif dalam penggunaan media sosial tersebut baik dari kalangan sekolah dasar, sekolah menegah hingga perguruan tinggi. 
Proses pembelajaran pada perguruan tinggi banyak dosen yang merekomendasikan para mahasiswa khususnya pada program studi Pendidikan Bahasa Arab, untuk menggunakan media sosial vlog sebagai media pembelajaran dan bahkan sebagai bahan tugas akhir pembelajaran sekaligus bentuk evaluasi. Hal ini sangat membantu sekali untuk meningkatkan kepercayaan diri para mahasiswa dan mengasah kemampuan mereka dalam berbahasa Arab terutama pada Maharah Kalam dimanapun dan kapanpun.

Dengan adanya media sosial vlog, kita bisa secara tidak langsung memaksakan diri untuk berani berbicara menggunakan bahasa Arab di depan kamera. Meskipun terkadang kita masih banyak yang merasa malu karena kurang terbiasa berbicara menggunakan bahasa Arab di depan kamera. Kemudian perbendaharaan kosakata bahasa Arab yang masih kurang sehingga masih banyak yang berfikir terlebih dahulu sebelum berbicara. Kegiatan Maharah Kalam akan terlihat menarik jika dikemas dengan media sosial vlog, meskipun para penonton atau pendengar tidak mengetahui berapa part yang harus diulang agar mendapatkan pelafalan bahasa Arab yang lancar.

Dari latar belakang di atas, penulis tertarik untuk mengetahui lebih jauh terkait penggunaan media sosial Vlog dalam pembelajaran bahasa Arab bagi mahasiswa fakultas Dakwah IAIN Kudus. Adapun rumusan masalah artikel ini adalah 1) bagaimana penggunaan media sosial Vlog pada pembelajaran maharah kalam? 2) bagaimana persepsi mahasiswa dalam penggunaan Vlog pada pembelajaran maharah kalah?.

\section{B. Pembahasan dan Hasil}

\section{Kajian Teori}

\section{a. Vlog atau Video Blogging}

Vlog atau vlogging (diucapkan "vlogging", bukan "v-logging"), atau vidblogging, merupakan suatu bentuk kegiatan blogging dengan menggunakan medium video di atas penggunaan teks atau audio sebagai sumber media perangkat seperti ponsel berkamera, kamera digital yang bisa merekam video, atau kamera murah yang dilengkapi dengan mikrofon merupakan modal yang mudah untuk melakukan aktivitas blog video. Sedangkan Pembuat Vlog biasa dikenal dengan sebutan Vlogger (Wikipedia Bahasa Indonedia:2020). Vlog atau video blog merupakan rekaman video singkat berisi mengenai opini, cerita atau kegiatan harian yang biasanya dibuat tertulis pada blog. Vlog pada mulanya merupakan sarana untuk mengekspresikan diri dan pendapat kepada publik (David 2017). Ia mulai menunjukkan eksistensi yang signifikan pada tahun 2004 dan baru menunjukkan popularitasnya yang meningkat pada awal 
tahun 2005. Hal tersebut ditunjukkan dengan meningkatnya keanggotaan grup blog video Yahoo! Secara dramatis pada tahun 2005 (Wikipedia).

Pada mulanya vlog tidak bersifat memberikan kontribusi pendidikan melainkan hanya sebagai bentuk ekspresi kehidupan sehari-hari, tempattempat wisata, trend fashion hingga tentang curahan hati baik kebahagiaan ataupun kesedihan. Menurut Indayatmi dari hasil penelitiannya Pada abad 21 terjadi pergeseran paradigma pembelajaran dalam dunia pendidikan yaitu dari teacher centered bergeser menjadi student active learning. Salah satu alternatif untuk mengurangi pembelajaran teacher centered, pendidik tidak hanya mengandalkan buku pegangan mengajar, tetapi harus dilengkapi dengan model pembelajaran yang tepat salah satunya media vlog yang mempunyai kelebihan yaitu peserta didik terlibat aktif didalamnya. Peserta didik dapat kreatif dalam membuat vlog, dan proses belajar mengajar menjadi menyenangkan (Indayatmi, 2018).

\section{b. Konsep Keterampilan Berbicara (Maharah Kalam)}

1) Pengertian Keterampilan Berbicara

Keterampilan berbicara (maharah kalam/ speaking skill) adalah kemampuan mengungkapkan bunyi-bunyi artikulasi atau kata-kata untuk mengekpresikan pikiran berupa ide, pendapat, keinginan atau perasaan kepada mitra bicara. Selain itu juga maharah kalam merupakan kombinasi fakto-faktor fisik, psikologis, neorologis, semantik dan linguistik secara luas sehingga dapat dianggap sebagai alat manusia yang paling penting bagi kontrol sosial. Tujuannya yaitu agar peserta didik atau mahassiswa mampu berkomunikasi secara lisan dengan baik dan benar (Tarigan, 1994).

2) Prinsip Pembelajaran Keterampilan Berbicara

Dalam pembelajaran keterampilan berbicara bagi non Arab berjalan dengan baik, maka harus diperhatikan hal-hal sebagai berikut (Rosyidi, 2012):

a) Hendaknya pengajar memiliki kemampuan yang tinggi tentang keterampilan ini.

b) Memulai dengan suara-suara yang serupa antara dua bahasa (bahasa siswa dan bahasa Arab).

c) Hendaknya pengarang dan siswa memperhatikan tahapan dalam pengajaran kalam, seperti memulai dengan lafadz-lafadz mudah yang terdiri dari satu kalimat, dua kalimat dan seterusnya.

d) Memulai dengan kosa kata yang mudah.

e) Memfokuskan pada bagian keterampilan bagi keterampilan berbicara, yaitu: 
(1) Cara mengucapkan bunyi dari makhrajnya dengan baik dan benar.

(2) Membedakan pengucapan harakat panjang dan pendek.

(3) Mengungkapkan ide-ide dengan cara yang benar dengan memperhatikan kaidah tata bahasa yang ada.

(4) Melatih siswa bagaimana cara memulai dan mengakhiri pembicaraan dengan benar.

f) Memperbanyak latihan-latihan, seperti latihan membedakan pengucapan bunyi, latihan mengungkapkan ide-ide.

3) Teknik Pembelajaran Keterampilan Berbicara

Beberapa Tektik pembelajaran yang dapat digunakan dalam meningkatkan keterampilan berbicara, diantaranya sebagai berikut:

a) Tanya Jawab

Tanya jawab merupakan sebuah Tektik dengan menekankan kemampuan bercakap-cakap dengan aktif. Metode ini termasuk kompetensi komunikatif yang menerapkan kaidah gramatikal suatu bahasa dalam membentuk kalimat yang benar dan untuk mengetahui kapan, di mana, dan kepada siapa kalimat itu diujarkan.

Dengan berbekal kompetensi komunikatif ini, seseorang dapat menyampaikan dan memproduksi suatu pesan atau menegosiasikan makna secara interpersonal dalam konteks yang spesifik. Krashen juga menegaskan bahwa kompetensi komunikatif lebih menekankan fungsi bahasa dalam komunikasi sesungguhnya daripada menguasai bentuk dan kaidah kebahasaan. Kaidah-kaidah kebahasaan itu hanya berfungsi untuk memonitor suatu bentuk ujaran (Muradi, 2014).

b) Menghafalkan Dialog

Dalam Tektik pembelajaran menghafal dialog ini diperkenalkan bentuk percakapan/dialog yang mengandung mufrodat dalam struktur kalimat yang dipergunakan. Untuk lebih efektif dalam melatih kemahiran bercakap-cakap penggunaan teknik pembelajar ini tidak sekedar menghafalkan dialog-dialog tersebut, akan tetapi juga mendemonstrasikannya. Ini dibuktikan dengan memperhatikan segi-segi ekspresi, mimik, gerak-gerik, dan intonasi sesuai dengan teks yang ditampilkannya.

Dialog tersebut harus disesuaikan dengan tingkat kemahiran dan harus bersifat situasional. Sedangkan, materi dialog tersebut diambil dari kehidupan sehari-hari, misalnya di rumah, di sekolah, di pasar, di stasiun dan sebagainya. Untuk menopang penciptaan situasi, dapat digunakan alat bantu seperti gambar-gambar, slide dan film (Kuswoyo, 2017). 
c) Percakapan Terpimpin

Di dalampercakapan terpimpin, pengajar menentukan situasi atau konteksnya. Siswa diharapkan mengembangkan imajinasi sendiri dalam percakapan dengan lawan bicaranya sesuai dengan topik yang telah ditentukan.Apabila siswa diberi kesempatan untuk mempersiapkannya di rumah, maka sebaiknya jangan ditetapkan pasangannya terlebih dahulu. Ini untuk menghindari kemungkinan siswa mempersiapkan dialog secara tertulis dan kemudian menghafalkannya. Kalau ini terjadi akan mengurangi nilai spontanitas.

d) Percakapan Bebas

Pada kegiatan pembelajaran dengan teknik percakapan bebas ini, pengajar hanya memberikan topik-topik pembicaraan. Siswa diberi kesempatan melakukan percakapan mengenai topik tersebut secara bebas. Agar proses pembelajaran berjalan dengan efektif, pengajar membagi siswa menjadi beberapa kelompok yang masing-masing beranggotakan 4 sampai dengan 5 orang, dengan tujuan siswa memiliki kesempatan yang cukup untuk berlatih. Dalam hal ini pengajar melakukan pengawasan atas berlangsungnya kegiatan pembelajaran terhadap masing-masing kelompok, dan memberikan perhatian khusus kepada kelompok yang dinilai lemah atau terlihat kurang lancar dan kurang bergairah dalam melakukan percakapan (Mustofa, 2011).

\section{Metode Penelitian}

Penelitian ini menggunakan jenis penelitian kualitatif deskriptif. Penelitian ini bertujuan untuk memberikan informasi atau gambaran yang meliputi tiga aspek, tempat, subjek, dan aktifitas (Sugiyono, 2015). Deskriptif sebagai pemecah masalah pada objek penelitian dengan cara menggambarkan dan mendiskripsikan situasi-situasi yang ada.

Fakus masalah dari penelitian ini adalah terkait dengan penggunaan Vlog pada kegiatan pembelajaran keterampilan berbicara (Mahārah kalām) untuk mahasiswa Fakultas Dakwah IAIN Kudus semester Ganjil TA 2019-2020 dan bagaimana persepsi mereka tentang penggunaan Vlog dalam kegiatan pembelajaran tersebut.

Teknik pengumpulan data pada penelitian ini dilakukan dengan cara triangulasi yang meliputi observasi, wawancara, dan dokumentasi. Observasi dilakukan untuk pengamatan secara langsung kegiatan pembelajaran bahasa Arab pada keterampilan berbicara (Mahārah kalām) di lapangan. Teknik 
wawancara langsung dilakukan kepada Dosen dan beberapa mahasiswa yang bersangkutan dengan tujuan untuk memperkuat hasil penelitian. Disamping wawancara kepada mahasiswa bertujuan sebagai penguat hasil penelitian, wawancara ini juga bertujuan sangat penting untuk mengetahui persepsi mereka mengenai proses pembelajaran dengan penggunakan Vlog dalam keterampilan bahasa Arab. Dokumentasi yang digunakan berupa foto dan record hasil vlog dari mahasiswa.

\section{Pentingnya Penggunaan Vlog untuk Meningkatkan Maharah Kalam}

Jika kita kaitkan antara vlog dengan maharah kalam maka keduanya mempunyai karakteristik yang sama. Keduanya memiliki kesamaan dalam hal audio visual. Keduanya membutuhkan suara dan penggambaran atau ekspresi pengungkapan bahasa. Dari hasil penelitian yang telah dilakukan oleh Mahfudz Rizki Mubarak dkk (IAIN Palangkaraya) ada tiga alasan pentingnya penggunaan vlog dalam pembelajaran maharah kalam. Pertama, vlog dan maharah kalam mempunyai kesamaan dalam bentuk ujaran verbal/lisan (Vetiana, 2019). Dosen berpandangan bahwa kesamaan karakteristik tersebut selain menguntungkan juga tidak menyulitkan bagi mahasiswa. Mereka hanya perlu menyiapkan Hp yang terdapat fasilitas kamera. Dan di zaman revolusi ini sudah tidak asing lagi para pengguna Hp Android. Kedua, tak sedikit mahasiswa yang kecanduan terhadap Gadget namun ke arah negatif dan hal tersebut dimanfaatkan ketika lengahnya dosen. Ketiga, dosen memberikan kesadaran bahwa Gadget tidak hanya dimanfaatkan sebagai alat permainan namun juga sebagai media pembelajaran (Mubarok, 2020).

Dari ketiga aspek di atas yang menjadi tujuan dari penggunaan vlog sebagai media pembelajaran adalah untuk menumbuhkan metal atau keberanian mahasiswa untuk mengujarkan kalimat berbahasa Arab. kekurangberaniaan ini kebanyakan dari mereka karena adanya sikap cemas dalam pembelajaran bahasa Arab. Dengan kata lain, media ini sebagai alternatif meminimalisir kecemasan dalam berbahasa Arab yang notabennya sebagai bahasa asing atau bahasa kedua bagi mereka. Menurut hasil observasi dalam proses pembelajaran Bahasa Arab faktor yang membuat Kecemasan berbahasa yang dialami oleh mahasiswa banyak ragamnya.

Bentuk kecemasan berbahasa Arab bagi mahasiswa berupa ketakutan dalam berkomunikasi. Kecemasan ini merupakan jenis rasa malu dengan karakteristik takut dalam berkomunikasi dengan orang lain. Baik kecemasan berbicara di depan umum maupun secara interpersonal. Yang pada akhirnya, 
membuat mahasiswa kurang percaya diri dalam mengungkapkan gagasan atau ide yang berada dalam pikiran mereka.

\section{Proses Pembuatan Vlog untuk Meningkatkan Maharah Kalam}

Ronny Yudhi mengemukakan pada penelitiannya bahwa hal-hal yang perlu diperhatikan atau tata cara pembuatan vlog (Priana, 2017). Tata cara ini bisa kita aplikasikan pada pembelajaran bahasa Arab di IAIN Kudus khususnya. Tata caranya sebagai berikut:

a. Inspirasi

Kita korelasikan antara inspirasi dengan tiga alasan yang sudah dirincikan sebelumnya (Mahfudz Rizki Mubarok dkk:2020) bahwa inspirasi ini muncul dikarenakan tiga alasan. Pertama, ada kesamaan antara vlog dengan maharah kalam yaitu bentuk ujaran verbal atau lisan. Kedua, peserta didik banyak yang memanfaatkan Gadget hanya untuk permainan semata. Ketiga, kurangnya kesadaran bahwa Gadget bisa dimanfaaatkan untu kepentingan pendidikan khususnya pembelajaran.

b. Tema

Menentukan tema sebelum membuat video. Dalam hal ini dosen memberikan tema yang terkait dengan أنشطة اليومية. Tema ini cukup ringan untuk digunakan mahasiswa sebagai bahan vlog nantinya. Di samping ringan, tema tersebut berkenaan kejadian-kejadian faktual yang dialami oleh mahasiswa. Setidaknya ada dua manfaat dengan pemilihan tema yang bersifat faktual, disamping lebih mudah dalam proses pengalihbahasaan, juga akan lebih membekas kata atau kalimat tersebut karena sering digunakan.

c. Membuat Skenario

Skenari dibuat untuk menyelaraskan alur. Mahasiswa mempersiapkan alur dengan rapi dan runtut dari awal sampai akhir. Sehingga pendengar bisa nyaman dan memahami apa yang disampaikan. Terkait tema الأنشطة mahasiswa menyiapkan bahan cerita (teks) tersebut mulai dari bangun tidur hingga malam beranjak tidur kembali. Alur ini sangat membantu mereka dalam proses berbicara yang sistematis dan padu.

d. Menyiapkan Tempat sebagai Latar Belakang

Tempat atau latar belakang video juga sangat mendukung unsur estetika atau kreatifitas dalam pembuatan video. Mahasiswa menggunakan 1 Lokasi atau lebih dari 2 lokasi sehingga menjadi semi film atau sejenis dokumenter. Semisal satu tempat kita bisa menggunakan taman atau di 
depan kantor rektorat sekaligus mempromosikan perguruan tinggi. Jika semisal lebih dari dua tempat kita bisa menggunakan rumah sendiri atau menyewa suatu tempat yang sesuai dengan tema. Pemilihan latar ini berdasarkan tujuan dari pembuatan video tersebut. setidaknya terdapat 2 alasan dalam mahasiswa membuat vlog, yakni alasan naturalisti dan alasan tertentu. Alasan naturalistik, mahasiswa memilih latar sesuai dengan kegiatan yang dilakukan dalam kegiatan tersebut. Alasan tertentu, seperti contoh untuk mempromosikan perguruan tinggi, dengan memilih latar di taman kampus atau rektorat.

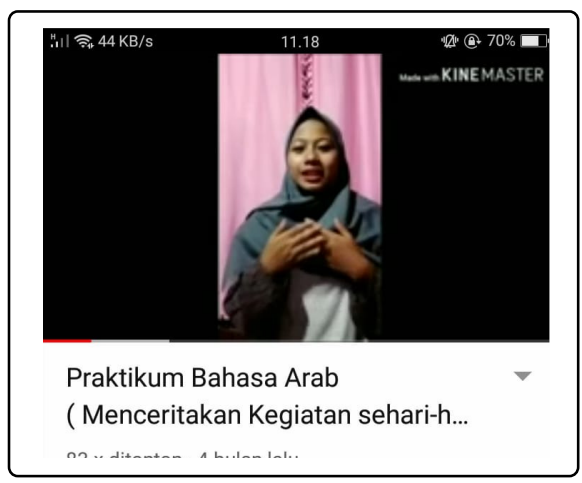

Gambar.1 latar naturalistik



Gambar.2 latar tujuan tertentu

e. Pencahayaan

Penchayaan merupakan salah satu elemen yang penting dalam menghasilkan video blogging (Vlog) berkualitas. Video yang berkualitas terdapat pencahayaan yang stabil agar menghasilkan gambar yang menarik. Pencahayaan tidak hanya sekedar apakah video dapat terlihat atau tidak. Lebih dari itu, dengan pencahayaan diharapkan akan membantu menciptaan suasana hati. Sumbernya bisa dari cahaya lampu 
dan cahaya matahari. Para vlogger mengenal istilah Golden Hour yang menjadi patokan dalam membuat sebuah video. Yakni, pagi hari mulai jam 6-9 dan sore mulai jam 4-6 sore, cahaya matahari di waktu-waktu tersebut sangat membantu membuat tampilan video lebih bagus. Ada 3 point penting dalam pencahayaan yaitu Back Ligh, Key Light dan Fill Light.

f. Objek

Mempersiapkan objek apa saja yang akan digunakan dengan maksud agar dalam proses pengambilan gambar tidak berulang-ulang hingga menggunaan waktu bisa efesien. Yang juga penting dalam pemilihan objek adalah bagaimana hasil Vlog tersebut bisa menarik sehingga banyak orang yang ingin melihatnya.

g. Pengambilan gambar

Setelah semua perangkat telah tersedia dan siap, langkah selanjutnya pengambilan gambar. Dalam pengambilan gambar mahasiswa menentukan titik-titik pengambilan gambar sesuai dengan pencahayaan.

h. Lihat hasil

Setelah pengambilan gambar yang dilakukan mahasiswa selanjutnya adalah melihat hasil. Tujuan melihat hasil pengambilan gambar untuk menjadi bahan evaluasi apakah sudah layak atau butuh sentuhan pada hal tertentu sebelum proses publishing.

i. $\quad$ Edit

Proses editing meliputi memilah dan memilih manakah bagian gambar yang layak dipublikasi.

j. Cek ulang

Proses ini mengecek hasil yang telah diedit dalam rangka penyempurnaan hasil gambar. Cek ulang dapat dilakukan berkali-kali disesuaikan keinginan dari vlogger tersebut.

k. Publikasi

Tahap terakhir dari proses pembuatan Vlog adalah publikasi. Tahapan ini dilakukan mana kala hasil rekaman dirasa sudah layak untuk disaksikan atau ditonton oleh orang lain. Pempublikasian ini bisa berada pada akun blog atau chanel yuotube yang dimiliki oleh mahasiswa.

Pada umumnya Penggunaan media pembelajaran berbasis ICT dapat meningkatkan minat belajar bagi mahasiswa, khususnya media pembelajaran kreatif seperti halnya Vlog. Pada praktiknya dosen sebatas memberikan arahan dan bimbingan kemudia mahasiswa dituntut kreatif. Bukan hanya kreatifitas yang diutamakan, akan tetapi kemampuan mahasiswa dalam menyalurkan ide 
dalam Vlog berupa presentasi bertema baik secara individu maupun kelompok. Sehingga pembelajaran menjadi lebih atraktif, kreatif dan menyenangkan.

\section{Kelebihan dan Kelemahan Penggunaan Vlog dalam Pembelajaran Maharah Kalam}

a. Kelebihan penggunaan Vlog dalam Pembelajaran maharah kalam

Dari beberapa tanggapan mahasiswa terkait penggunaan Vlog sebagai media pembelajaran terupa pembelajan bahasa Arab dalam meningkatkan maharah kalam menyatakan bahwa terdapat nilai yang positif. Mereka beranggapan bahawa penggunaan media ini membantu dalam meningkatkan kepercayaan diri untuk lebih aktif dalam berbicara bahasa Arab. Diantara nialai positif yang bisa diambil dari penggunaan media vlog adalah sebagai berikut;

1) Menumbuhkan sikap confidence

Keberhasilan pembelajaran bahasa pada keterampilan berbicara atau kalam salah satu modal utama adalah percaya diri. Sikap confidence ini yang membuat seseorang mampu mengutarakan homprehensi yang ada dalam dirinya dalam bentuk persepsi ujaran. Mahasiswa menggunakan media vlog sebagai sarana pembelajaran berbica untuk bahasa kedua (bahasa Arab) memilki sensasi tersendiri. Untuk mencapai percaya diri, mereka memerlukan persiapan yang begitu panjang. Persiapan ini sebagai latihan untuk perform di hadapan orang lain dengan menggunakan bahasa Arab sebagai bahasa komunikasi. Walaupun komunikasi ini masih bersifat satu arah, media ini mampu memberikan sebagian besar yang menggunakannya percaya diri dalam pembelajaran.

2) Mudah dan fleksibel

Sebenarnya perangkat utama untuk membuat Vlog adalah Gadget. Kemudahan dalam pembuatan media Vlog ditunjukkan dengan perangkat elektronik yang tersedia dalam Gadget tersebut. Dalam Gadget difasilitasi teknologi perekam gambar atau yang sering disebut kamera. Nilai fleksibel ini memberikan kemudahan bagi mahasiswa untuk membuat media pembelajaran yang berupa vlog. Kemudahan ini juga tampak mana kala proses publishing yang membutuhkan jaringan internet di dalam perangkat Gadget sudah tersedia.

3) Murah dan ekonomis 
Nilai ekonomis pada media ini adalah kebanyakan dari siswa memiliki Gadget. Hal ini selaras dengan perangkat utama dari Vlog tersebut. Dengan kata lain mahasiswa tidak perlu membutuhkan perangkat lain sebagai modal pembelajaran tambahan. Cukup memanfaatkan apa yang dimiliki dalam rangka meningkatkan kemampuan berbicara bahasa Arab mereka.

4) Meningkatkan kreatifitas

Penggunanan Vlog sebagai media pembelajaran mamapu meningkatkan kreatifitas mahasiswa dalam menghasilkan vedio vlogging yang akan dimuat pada media sosial. Hasil kreatifitas yang telah dipublish memungkinkan bagi mahasiswa menambah percaya diri dalam berbicara bahasa Arab pada kesempatan yang lain. Hasil video yang akan ditampilkan juga berdampak pada motivasi bagi penonton untuk belajar bahasa Arab.

b. Kelemahan penggunaan Vlog dalam Pembelajaran maharah kalam

Disamping penggunanaan Vlog memiliki nilai positif atau kelebihan dalam pembelajaran berbicara bahasa Arab, juga memiliki nilai negatif atau kelemahan. Peneliti menemukan kelemahan dalam penggunaan Vlog sebagai media pembelajaran, diantaranya ada kurang transparannya mahasiswa dalam pengujaran bahasa Arab secara natural tanpa membaca teks. Ketika dalam proses perekaman video ada mahasiswa yang menyembunyikan teks/naskah di balik kamera sehingga hasil berbicara berasal dari membaca. Kelemahan ini kontradiktif dengan sikap positif yang menyatakan bahwa Vlog dengan pemanfaatan Gadget memiliki nilai fleksibel.

Kelemahan selanjutnya adalah hasil ujaran yang ditampilkan dalam Vlog rentang dengan kesalahan pengunaan qawaid. Kesalahan ini banyak pada tataran morfologi (sharaf) dan sintaksis (nahwu). Sebagai contoh kesalahan dalam morfem adalah ketidaksesuaian penggunaan jenis kata mudzakar diucapkan muanats dan sebaliknya. Dalam sintak, banyak mahasiswa yang belum bisa membedakan susunan frasa, yakni susunan mudlof - mudlof ilaih dan naat-man'ut. Ada juga yang menggunakan tarkib idlofah tapi tidak sesuai dengan persyaratan yang ditetapkan dalam menyusun tarkib idlofah.

\section{Simpulan}

Penggunaan media pembelajaran berbasis Informasi Telekomunikasi dan Komputer disamping mengasyikkan juga mampu memberikan motivasi belajar 
terutama bagi mahasiswa. Vlog yang merupakan jenis media belajar dengan memanfaatkan teknologi tersebut memberikan sumbangsih atas peningkatan hasil belajar. Pemilihan Vlog pada pembelajaran kemampuan berbicara menjadi salah satu media yang digunakan mahasiswa karena memiliki banyak nilai positif atau kelebihan. Diantara kelebihan yang ada dalam media ini adalah bersifat mudah dan fleksibel; murah dan ekonomis; dan meningatkan kreatifitas mahasiswa.

Dalam praktinya, penggunaan Vlog mampu meningkatkan perfomansi atau percaya diri dalam berbicara bahasa Arab. Mahasiswa yang memiliki percaya diri yang tinggi untuk berbahasa akan mampu menyampaikan ide, gagasan, atau pikiran dengan baik. Meskipun terkadang masih terdapat kesalahan dalam struktur kalimat yang digunakan, akan tetapi maksud dan tujuan dari suatu pembicaraan bisa tersampaikan. 


\section{Daftar Pustaka}

David, Eribka Ruthelia. dkk. 2017. “Dkk, Pengaruh Konten Vlog Dalam Youtube Terhadap Pembentukan Sikap Mahasiswa Ilmu Komunikasi Fakultas Ilmu Sosial Dan Politik Universitas Sam Ratulangi." Acta Diurna 6 (1).

Haniah. 2014. "Pemanfaatan Teknologi Informasi Dalam Mengatasi Masalah Belajar Bahasa Arab 2014." Al-Ta'rib 2 (1).

Indayatmi. 2018. "Pengaruh Vlog Pembelajaran Terhadap Peningkatan Hasil Belajar Peserta Didik Smk Negeri 2 Depok." Jurnal Pendidikan Sains 6 (1).

Kuswoyo. 2017. “Konsep Dasar Pembelajaran Maharah Al-Kalam.” An-Nuha 4 (1): 6.

Mubarok, Mahfudz Rizki. dkk. 2020. "Penggunaan Vlog Dalam Pembelajaran Maharah Kalam." Al-Mi'yar 3 (1).

Muradi, Ahmad. 2014. "Pendekatan Komunikatif Dalam Pembelajaran Bahasa Arab." Arabiyat: Jurnal Pendidikan Bahasa Arab Dan Kebahasaaraban 1 (1): 33.

Mustofa, Syaiful. 2011. Strategi Pembelajaran Bahasa Arab Inovatif. Malang: UINMaliki Press.

Priana, Ronny Yudhi Septa. 2017. "Pemanfaatan Vlog Sebagai Media Pembelajaran Terintegrasi Teknologi Informasi." Prosiding Seminar Nasional FKIP, 1 (2).

Rosyidi, Abd Wahab \& Mamluatul Ni'mah. 2012. Memahami Konsep Dasar Pembelajaran Bahasa Arab. Malang: UIN- Maliki Press.

Sugiyono. 2015. Metode Penelitian Pendidikan. Bandung: Alfabeta.

Tarigan, Hanry Guntur. 1994. Menyimak Sebagai Suatu Keterampilan Berbahasa. Bandung: Penerbit Angkasa.

Vetiana, Gautama Veri. 2019. "The Role of the Center for Language Improvement in Enhanching Speaking Skills of The Class One of The Modern Islamic Boarding School Darussalam Gontor at The Girls' Second Campuss (Ar),." Al-Ta'rib: Jurnal Ilmiah Program Studi Pendidikan Bahasa Arab IAIN Palangka Raya 7 (2). 
